\title{
Exogenous and Endogenous Learning Resources in the Actiotope Model of Giftedness and Its Significance for Gifted Education
}

Journal for the Education of the Gifted 2017, Vol. 40(4) 310-333

(C) The Author(s) 2017

Reprints and permissions: sagepub.com/journalsPermissions.nav DOI: $10.1177 / 0162353217734376$ journals.sagepub.com/home/jeg

@SAGE

\section{Albert Ziegler', Kimberley L. Chandler², Wilma Vialle³, and Heidrun Stoeger ${ }^{4}$}

\begin{abstract}
Based on the Actiotope Model of Giftedness, this article introduces a learningresource-oriented approach for gifted education. It provides a comprehensive categorization of learning resources, including five exogenous learning resources termed educational capital and five endogenous learning resources termed learning capital. Evidence from the literature is presented that supports the validity of each of the categories. Finally, 12 implications of a learning resource orientation for gifted education are discussed in relation to four areas: gifted education orientations, gifted identification, gifted education principles, and gifted learning resources management.
\end{abstract}

\section{Keywords}

giftedness, learning resources, educational capital, learning capital, Actiotope Model of Giftedness

\section{A Learning Resource View}

There are many ways to scientifically understand and capture the complexity of the development and learning of gifted individuals (Sternberg \& Davidson, 2005). Recent approaches, which are gaining influence, try to overcome the traditional focus on the

\footnotetext{
University of Erlangen-Nuremberg, Erlangen, Germany

${ }^{2}$ The College of William \& Mary, Williamsburg, VA, USA

${ }^{3}$ University of Wollongong, Wollongong, Australia

${ }^{4}$ University of Regensburg, Regensburg, Germany

Corresponding Author:

Albert Ziegler, Schloßplatz 4, 91054 Erlangen, Germany.

Email: albert.ziegler@fau.de
} 
individual and instead conceptualize talent development as an interaction of an individual with internal and external learning resources. Examples include sociocultural (Plucker \& Barab, 2005; Reis, 2005; Valsiner \& Rosa, 2007), developmental-relational (Dai \& Chen, 2013; Lerner \& Overton, 2008), epigenetic (Jablonka \& Lamb, 2005; Simonton, 2005), and dynamic systems (e.g., Jeltova \& Grigorenko, 2005; Kelso, 2003; Ziegler \& Phillipson, 2012) approaches. In this article, we outline a theory of resource-oriented gifted development based on systems theory (Ziegler \& Baker, 2013; Ziegler, Stoeger, \& Balestrini, 2017). It does not seek to replace other models of giftedness but rather to complement them. Indeed, by offering many new perspectives, we posit that such an approach is fruitful not only for giftedness research but also for the practice of gifted education.

In the past, gifted education focused predominantly on gifted individuals and aimed at providing them with optimal conditions in which to flourish (Ziegler \& Phillipson, 2012). However, within both research and practice, there has long been a profound interest to not only identify gifted individuals but also to identify what has been described as "gifted environments" (Mirman, 2003), "smart contexts" (Barab \& Plucker, 2002), or "talent hotspots" (Coyle, 2009). These concepts share the idea that not only do individuals differ in their potential to attain extraordinary accomplishments but also environments differ in their potential to make extraordinary accomplishments possible. For example, an astonishingly high number of eminent performers learned in institutions like the Meadowmount School of Music in Westport, New York, or the Spartak Tennis Club in Moscow, Russia (Coyle, 2009). We posit that such gifted environments are characterized by the richness of learning resources that they provide. However, learning resources are located not only in the environment but also within the individual, thus making it necessary to devise a theory that encompasses both: exogenous learning resources outside the individual and endogenous learning resources within the individual. These resources serve two main functions: Endogenous learning resources are necessary to process and make full use of exogenous learning resources and they underlie effective actions.

\section{Two Types of Learning Resources}

Resources are the means that can be employed to attain goals. Therefore, learning resources can be employed to attain learning goals. The question remains, however, whether it is possible to determine an exhaustive categorization of the relevant learning resources that are conducive for gifted development and learning.

Ziegler and Baker (2013) suggested such a categorization of learning resources based on the Actiotope Model of Giftedness. This model is based on dynamic systems theory (Ziegler, 2005) and posits that the unit of analysis is no longer the gifted individual, but the entirety consisting of the individual and his material, social, and informational environments. This entirety was termed an actiotope (Ziegler, Vialle, \& Wimmer, 2013). Thus, an actiotope has an individual component and an environmental component, which is constituted through the actions of the individual. A systematic categorization of learning resources needs to distinguish between endogenous learning 
resources within the individual component and exogenous learning resources within the environmental component of the actiotope. Ziegler and Baker termed endogenous learning resources as learning capital, and exogenous learning resources as educational capital. Table 1 provides definitions of the types of capital as well as some examples for illustrative purposes. Some comments on the logic of the capitals can be found in the footnote to the table. In the remainder of this article, we will provide some evidence from the literature to demonstrate the significance of the 10 postulated capitals. Indeed, there is ample evidence that each of the capitals is associated with the acquisition of effective action repertoires. Following this explication, we present 12 implications of a resource-oriented approach for gifted education. Most of these will reveal that the capitals are not separate but interacting entities.

\section{Educational Capitals}

Economic educational capital. Numerous studies show the relationship between parents' socioeconomic status (SES) - and thereby economic educational capital — and students' school achievement (e.g., Ditton \& Krüsken, 2009; Ehmke \& Jude, 2010). On average, children from low-SES families attain lower levels of scholastic achievement, profit less from similar educational measures, and choose less prestigious school tracks and university majors.

There are also studies that show the relationship between economic educational capital and achievement in nonacademic domains. For example, successful individuals in sports quite often come from high-SES families who spend above-average amounts of money on sports education (Beamish, 1990). Similar results were found for musically talented students (Manturzewska, 1990) and successful chess players (Roring, 2008).

However, educational capital bears a relationship to achievement not only at the individual or family level but also at the level of the educational system. For example, analyses by the Organisation for Economic Co-Operation and Development (OECD; 2001) show relationships between the gross national product of countries and the achievement levels of students in these countries. About $27 \%$ of achievement differences in the Program for International Student Assessment (PISA) results can be explained by the gross national product of a country (OECD, 2001).

In addition, on a societal level, there seem to be accumulations of achievement excellence that are related to economic capital (e.g., Hanushek \& Kimko, 2000; Lynn \& Vanhanen, 2002; Rindermann, Sailer, \& Thompson, 2009). Individuals who work at research institutions in rich countries with high gross national products most often win Nobel prizes (Statista, 2016). One reason for this might be that many research fields (e.g., particle physics, gene technology) necessitate high investments (see also Ammermüller \& Lauer, 2007).

Infrastructural educational capital. The number of books in a household predicts students' reading motivation and achievement (Anger, Plünnecke, \& Tröger, 2007; Baumert, Stanat, \& Watermann, 2006; McElvany, Becker, \& Lüdtke, 2009; Suchań \& 


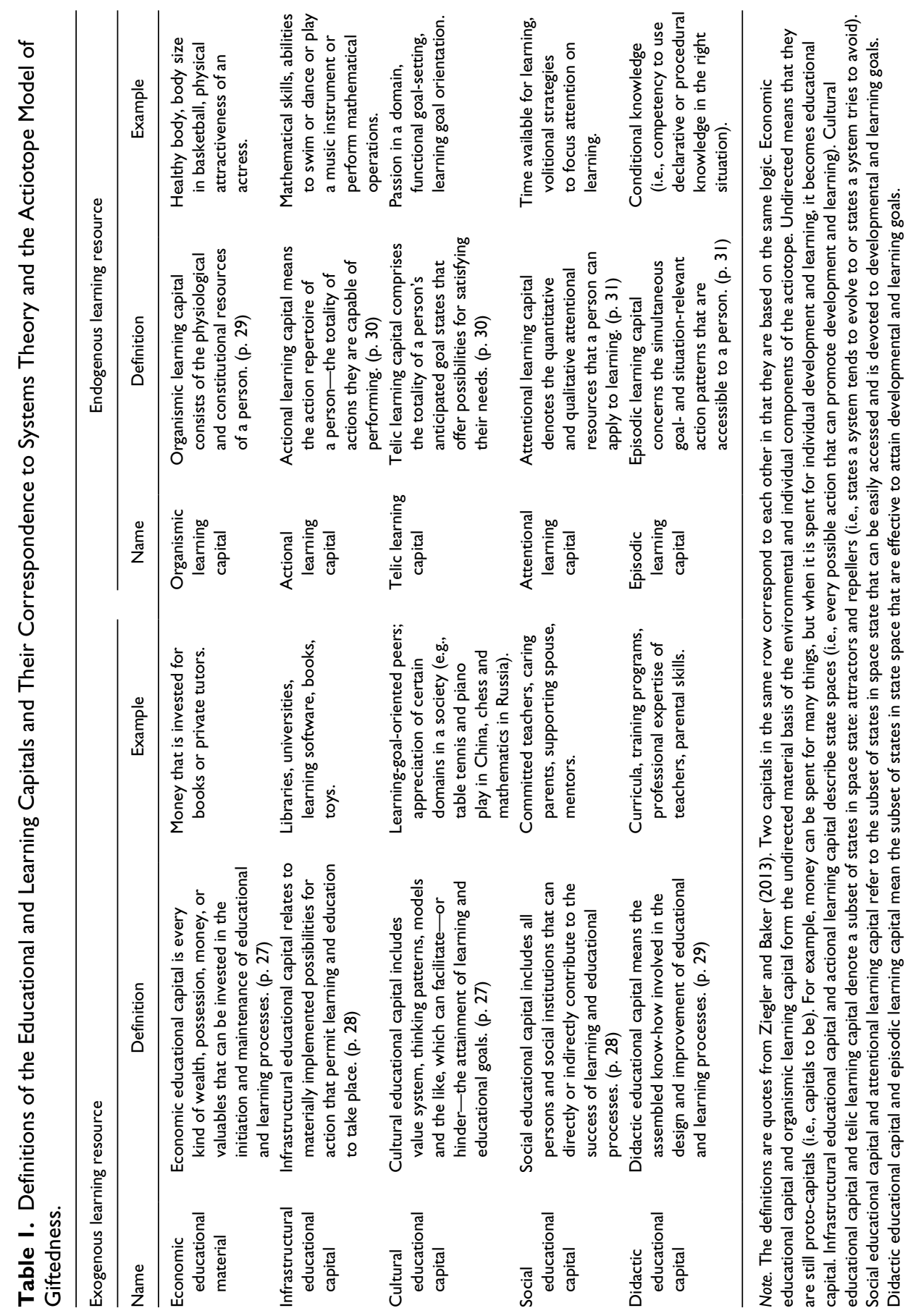


Bergmüller, 2010), and students who own a computer attain better grades in mathematics and sciences (Downey \& Vogt Yuan, 2005). Furthermore, educational institutions play an important role in achievement development. For example, individuals who attend early childhood education institutions subsequently attain higher educational levels and children who attend kindergarten for more than 1 year show significantly higher reading competencies at the end of primary school (Cunha \& Heckman, 2007). Importantly, there is now evidence regarding how investment in infrastructural capital can increase achievement levels and economic growth (e.g., Institut der Deutschen Wirtschaft Köln, 2015).

Cultural educational capital. Various studies have shown that the more positive parents' and peers' values, attitudes, and beliefs about learning and education are, the better pupils' achievements tend to be (Fuligni, 1997; Ryan, 2000). This relationship has been documented not only for the academic domain but also for various other talent domains, such as music (Davidson, Howe, Moore, \& Sloboda, 1996).

There are also studies in schools that show that the values, attitudes, and beliefs about learning and education held on a school level influence achievement. For example, in a study with 10,187 students from 160 secondary schools, Lee and Bryk (1989) found that students who attend schools with a mission statement that emphasizes the value of learning and education reach higher achievement levels.

On a societal level, too, values, attitudes, and beliefs about learning and education positively influence achievement levels. One example is Confucian-heritage societies that highly value learning and education (Li, 2004; Shek \& Chan, 1999) and whose students, on average, reach higher achievement levels than students from other cultures (McInerney, 2008; Phillipson, Stoeger, \& Ziegler, 2013).

There are also examples of negative cultural educational capital. One such example is negative gender stereotypes in science, technology, engineering, and mathematics (STEM; Steele, 1997). The widespread stereotype that girls and women are less talented for STEM leads to lower participation rates of women in STEM (Stoeger, 2007) and - as is shown by research studies on stereotype threat - to lower the achievement levels of girls and women in these domains (Shih, Pittinsky, \& Ambady, 1999).

Social educational capital. Various studies show that individuals who achieve excellence in a talent domain often had a mentor during their formative years (Stoeger, Ziegler, \& Schimke, 2009). In their studies, Gruber, Lehtinen, Palonen, and Degner (2008) substantiated the role of teachers, coaches, and mentors for the development of excellence in the domains of music, management, and economy. The importance of social capital has also been shown in the academic area (Hattie, 2008; Seidel \& Shavelson, 2007). Here, too, there seem to be relatively large cultural differences. Parents in East Asian society show more support for their children, independently of their SES (Hong \& Ho, 2005; MacLeod, 1987; Schneider \& Lee, 1990; Stevenson, Lee, \& Stigler, 1986). For example, they spend more time on supporting their children and even orient their residential decisions on the learning and scholastic needs of their children (Vialle, 2013). 
Didactic educational capital. Studies show that especially during early childhood, didactic education capital — particularly the qualification of caregivers - plays an important role (Institut der Deutschen Wirtschaft Köln, 2015). Similar results were reported for the scholastic area. Pupils' performance is clearly influenced by their teachers' qualifications and the quality of instruction (Darling-Hammond, 2000; Hattie, 2008; Seidel $\&$ Shavelson, 2007), even when the pupils' SES and language competence were statistically controlled.

Didactic educational capital in the form of one-on-one learning processes such as mentoring or individual coaching seems to be especially effective (Stoeger et al., 2009). The important role of one-on-one instruction was already emphasized by Bloom (1984), who compared a number of instructional methods and clearly showed that individual instruction provided by a pedagogically trained tutor or mentor represented the most effective didactical capital.

There has been a substantial increase in didactic capital in many domains during the last few decades. For example, in sports, training methods have improved enormously; there are increasing numbers of research groups that test different training approaches against one another (e.g., Fletcher \& Jones, 2004; Lehmann et al., 1992), and the results are used to improve training. Similar changes can be discerned for the domain of music where parents are trained how to best support their young children's music instruction (e.g., Starr, 1976). In the scholastic area, there are also continuous efforts to improve curricula and educational standards (Klieme, 2004) as well as teacher training and professional development of teachers (Institut der Deutschen Wirtschaft Köln, 2015).

\section{Learning Capitals}

Organismic learning capital. There is ample evidence that physical fitness and various aspects of learning behavior and performance are closely associated. For example, bodily fitness correlates with performance in memory tasks (Chaddock, Hillman, Buck, $\&$ Cohen, 2011), IQ (Aberg et al., 2009), and scholastic achievements (Curcio, Ferrara, $\&$ De Gennaro, 2006; Smith, 2001). Knowledge of these results makes it even more disturbing that up to one third of children in industrialized societies showed deficient levels of physical activity and bodily fitness (Ekelund et al., 2012; Shore et al., 2008).

Studies from the field of expertise research also show that when planning their daily schedules and training, experts include aspects that optimally use or optimize their organismic learning capital within their regimens (Ericsson, Krampe, \& TeschRomer, 1993).

Actional learning capital. The competence to conduct certain actions, including on a cognitive level, influences learning success in multifaceted ways. For example, there are numerous studies that underline the importance of learning strategies for successful learning (Hattie, Biggs, \& Purdie, 1996; Mandl \& Friedrich, 2006), the importance of knowledge structures for organizing and comprehending new information (Chi, Glaser, \& Farr, 1988), or the importance of athletes' levels of flexibility for the execution of certain sequences of movements (Starkes \& Ericsson, 2003). 
There are also studies on relationships between low levels of actional learning capital and achievement development. For example, language competency difficulties usually decrease achievement levels. One example of learners with low actional learning capital with regard to language competencies is those students whose schooling occurs in a language different from their home language. They are often less effective at expressing themselves in the language of their schooling and are in many cases less effective at executing mental operations than they would be in their native language. This is vividly underlined by studies on IQ. IQ tests for the same person conducted in different languages typically produce results differing by an entire standard deviation (Sotelo-Dynega, Ortiz, Flanagan, \& Chaplin, 2013).

Telic learning capital. The long-term goals a person pursues can have an important impact on later competencies. This was shown, for example, by results of the 16th Royal Dutch Shell survey. Children from high-SES families had higher career goals and were more optimistic about reaching these goals (40\% vs. $17 \%$ of the low-SES study participants). Furthermore, a study by Bandura, Barbaranelli, Caprara, and Pastorelli (2001) emphasized the importance of long-term goals. In their study, SES was only linked to children's career trajectories indirectly through its effects on parents' perceived efficacy and academic aspirations. The impact of parental self-efficacy and aspirations on their children's perceived career efficacy and choice was, in turn, entirely mediated through the children's perceived efficacy and academic aspirations.

However, it is not only long-term goals that are important for achievement development. There are also numerous studies that underline the importance of short-term goals (e.g., Harackiewicz, Barron, Tauer, \& Elliot, 2002) for learning and achievement. When it comes to the development of achievement excellence in a talent domain particularly, fine-tuned learning goals play an important role. In the context of deliberate practice, learners set learning goals that help to eliminate weaknesses and optimize successful actions on continuously higher levels (Ericsson, 1996).

Attentional learning capital. Both the quantity and quality of attentional learning capital are important for talent development. Numerous studies show that the quantity of attentional capital (e.g., the time students concentrate on their learning or homework) has an influence on achievement levels (e.g., Klein, 2001; Paschal, Weinstein, \& Walberg, 1984) and that students who manage to avoid distractions attain better achievements (Lupatsch \& Hadjar, 2011; Mößle, Kleimann, Rehbein, \& Pfeiffer, 2006). However, the quality of attentional capital seems to be even more important (e.g., Dettmers, Trautwein, Lüdtke, Kunter, \& Baumert, 2010), especially when it comes to achievement excellence (Ericsson, 2006). In expertise research, attentional learning capital is seen as one of the best predictors of improved achievement levels:

The requirement for concentration sets deliberate practice apart from both mindless routine performance and playful engagement, as the latter two types of activities would, if anything, merely strengthen the current mediating cognitive mechanisms rather than modify them to allow increases in the level of performance. (Ericsson, 2006, p. 794) 
These assumptions are supported by empirical research (Ericsson, 2001, 2003).

Episodic learning capital. Episodic learning capital comprises action patterns available to individuals based on their goals and the situation in which they act. In this respect, episodic learning capital differs from actional learning capital as it links available actions with developmental and learning goals and the contextual features. This differentiation is also shown by research. For example, even if students know how to use cognitive or metacognitive learning strategies (actional learning capital), that does not mean that they have the conditional knowledge for when these strategies can be successfully deployed, which in turn may not lead to increases in performance.

The importance of episodic learning capital for the development of excellent achievements is shown by expertise research (Ericsson, Charness, Feltovich, \& Hoffman, 2006). Relatively independent of the talent domain, a broad action repertoire (actional learning capital) is needed that continually has to be broadened by setting optimal learning goals (telic learning capital) and applying the actions in a way that is appropriate for the given context (e.g., practice, competitions, training; see Ericsson et al., 1993).

\section{New Perspectives for Gifted Education}

A resource orientation offers new perspectives for gifted education. In the following, three representative examples are introduced for each of four different areas: gifted education orientations that specify the outcomes that gifted education is aiming to attain, identification, basic educational principles, and learning resources management.

\section{Gifted Education Orientations}

Positive gifted education. More than three decades ago, Abraham Maslow (1987) argued that instead of focusing predominantly on treating mental illnesses, psychology should focus on personal growth and leading a satisfactory life. This position was revived by Seligman and Csikszentmihalyi (2000) and became popular under the label of positive psychology. A similar new perspective may be of interest for gifted education, leading to what might be called a positive gifted education. Indeed, in a recent meta-analysis, Preckel and Krampen (2016) found that in PsycINFO, during the time period of 1980 to 2014, publications on psychological disorders (e.g., Asperger syndrome, depression) outnumbered publications on topics related to well-being (e.g., happiness, life satisfaction) in a ratio of 2.5:1. However, a closer inspection of the latter literature reveals that most of the works still refer to deficits in the indicators of well-being. In contrast, a resource-oriented perspective, although by no means denying that many things can go wrong in the development of gifted individuals, takes a much more positive perspective in evaluating which strengths and resources the individual has at his or her disposal. Consequently, it focuses instead on the possibilities for a gifted individual and seeks to design learning pathways (see below) to these goals instead of asking what might go wrong and what doors may already have been shut. 
Homeostatic and homeorhetic educational orientations. There is an ongoing debate as to which paradigm might be best suited for gifted education (Dai \& Chen, 2013; Subotnik, Olszewski-Kubilius, \& Worrell, 2011; Ziegler, Stoeger, \& Vialle, 2012). In particular, there have been some discussions whether outstanding achievement or eminence ought to be the chief goal of gifted education (Subotnik et al., 2011) or if we should focus instead on the needs of the gifted (Feldhusen, 1982). From a resourceoriented perspective, both orientations make sense, the former reflecting a homeorhetic and the latter a homeostatic orientation. Whereas the homeorhetic educational orientation focuses on growth, the homeostatic educational orientation focuses on balance. Expressed in more technical language, homeostasis denotes the process by which a system returns to a particular state. Homeorhesis, on the contrary, is the process by which a dynamic system returns to a trajectory.

Systems need a constant influx of resources to regulate themselves so that their internal conditions remain stable and function within a normal range. This type of balance is called homeostasis (from the Greek "homo" for "similar" and "stasis" for "standing still"). It underlies important processes such as sleep regulation, thermoregulation, and stress regulation. However, there are well-known factors that threaten the balance within gifted individuals. Examples are underachievement due to boredom, twice-exceptionality, and negative consequences of being labeled as gifted (Shavinina, 2009).

Although humans try to keep their system in a normal state in many aspects, they obviously do not stay the same. Prime examples are development and learning; when there is a constant dynamic tension between homeostasis and change, the educational orientation is then better characterized as a growth-oriented homeorhetic educational orientation. In particular, due to their special talents, gifted individuals can undergo dramatic changes when they increase their skill levels. The objective of gifted education, then, is not to maintain homeostasis, but rather to challenge homeostasis and then to reestablish it at a different (skill) level. To make this dynamic work, an individual has to coevolve the resources as well as their actiotope (see Ziegler \& Phillipson, 2012).

Robustness and resilience. Although robustness and resilience often are considered to have similar meanings, from a resource-oriented perspective there are important differences. Kitano (2004) defined robustness as "a property that allows a system to maintain its function despite external and internal perturbations" (p. 826). In contrast, resilience requires novelty and adaptation (C. R. Allen \& Holling, 2008; Gunderson, Folke, \& Janssen, 2006). A popular example is a tree during a storm: It can either resist the storm with a strong trunk (robustness) or adapt and bend (resilience). In a similar vein, an individual might possess resources that enhance robustness. For example, a learning goal orientation (and thus telic learning capital) enhances an individual's robustness when facing negative feedback. A learning-goal-oriented person conceives of it as a learning opportunity (Dweck, 1999). In contrast, a modification theory of one's intelligence (and thus episodic learning capital) can enhance resilience as it enables the individual to adapt after receiving negative feedback (e.g., by increasing his or her effort; Dweck, 1999). 
We do not claim that robustness and resilience have not yet been topics of gifted education, but to date they have been predominantly viewed from a loss perspective and not from the positive gifted education perspective advocated here. In a series of studies conducted in different countries (Vladut, Liu, Leana-Taşc1lar, Vialle, \& Ziegler, 2013; Vladut, Vialle, \& Ziegler, 2015), it was shown that students who possess more educational and learning capitals are more robust and more resilient. For example, their self-confidence is higher, they process negative feedback in a more constructive way, and they more likely subscribe to a modification theory. Thus, they are much better suited to growth.

At first glance, it may seem paradoxical that gifted individuals who are rich in educational and learning capitals and have good opportunities to develop need in turn even more educational and learning capitals to cope with the consequences of this development. A popular example from the giftedness literature shows that this assumption is not a paradox at all: Teachers might feel threatened by their gifted students or peers may denounce their gifted peers as nerds, both of which are unpleasant experiences for many gifted students; they must then devise coping strategies and therefore require more resources (Oh et al., 2015). Thus, the focus on positive developments has to be done with an eye on the possible unwanted side effects of individual growth. However, as gifted students are often resource-rich students (Ziegler, Debatin, \& Stoeger, 2017), there is no need for an educator of the gifted to be pessimistic, but rather to be prepared.

\section{Identification}

Availability of educational and learning capitals. The availability of educational and learning capitals can be measured with specifically tailored instruments. Two instruments are currently available. One is a Teacher Checklist, which has satisfactory psychometric properties and predicts standardized achievement scores and school grades very well (Harder, Trottler, Vialle, \& Ziegler, 2015; Harder, Trottler, \& Ziegler, 2013). A culturally adapted version of this checklist was used for the statewide identification of gifted students in the United Arab Emirates (Ziegler \& Stoeger, 2016). In addition to measurements of action-based skills in scholastic settings, educational and learning capitals were both addressed. Subsequent research shows that educational and learning capitals added incremental validity beyond an intelligence measurement (Ziegler et al., 2017). Indeed, they proved to be an even better predictor of scholastic achievements than IQ. The other instrument currently available is the Questionnaire for Educational and Learning Capital (QELC; Vladut et al., 2013; Vladut et al., 2015), which also has strong psychometric properties and has been successfully used in many studies. For example, more educational and learning capitals as measured with the QELC are associated with higher school achievements and failure coping (Leana-Taşcılar, 2015; Vladut et al., 2015). Modified versions of the QELC have been used in expertise studies, too. For example, world-class long-distance runners, highly successful women in the STEM field (professors or leading positions in private companies), and professional musicians (successful at a national level) have clearly been shown to have more educational and learning 
capitals at their disposal than comparable control groups (e.g., long-distance runners successful on a national level, women who have acquired a degree in a STEM subject but been less successful, musicians successful at a regional level).

In addition to specifically tailored measurement instruments for educational and learning capitals, it is possible to use concrete indicators of the capitals. For example, Veas, Castejón, O’Reilly, and Ziegler (2017) used a complex measure of different aspects of parental involvement as a representative for educational capital and a measurement of elaboration learning strategies and metacognitive learning strategies as representatives of learning capital.

Synchronization. Recently, Debatin, Hopp, Vialle, and Ziegler (2015) initiated a research program about a phenomenon they termed domain impact level on activities. The basic idea is that learning will affect increasing aspects of an individual's actiotope and in a sense spread through the whole actiotope. For example, a comparison of the books, friends, and leisure activities of a professional chess player and a professional soccer player will differ markedly. The chances are high that the contents of the books, the interests of the friends, and the leisure activities of the chess player are much more closely associated with chess, whereas similar strong ties to soccer will be probably found for these aspects for the soccer player. Thus, with increasing skill level, the respective domain increasingly penetrates the actiotopes of an individual. Nonsynchronization of resources makes learning much more difficult, as is shown by impaired scholastic learning of gifted students whose friends are alienated from school.

In our own research, we have used an event sampling method (Debatin et al., 2015). For example, participants of various expertise levels were asked to indicate for a number of their daily actions which of these actions have been in any way influenced by their domain. Examples might include talking about chess at breakfast, spending less time with their partner in favor of more training hours, and playing chess while commuting (Debatin et al., 2015). In another study (Ziegler et al., 2017), we asked secondary school students, on a timetable for a week partitioned into 1-hour intervals, to list what they typically do during these time intervals in a normal school week and in a normal holiday week. Then for each entry, they were asked several questions about their learning and the availability of learning resources. Those students who made more positive use of social and infrastructural educational capital (e.g., talking positively about schools with parents during breakfast rather than talking about other topics, studying while commuting to school instead of listening to music), and thereby synchronized their actiotope better with regard to school, exhibited much better school achievements.

Tension zones. A synchronization of resources refers to a certain point in time. However, a dynamic perspective goes beyond the moment and asks for developmental dynamics and the resources necessary for growth. Here, the identification of tension zones is of utmost importance. A tension zone is usually defined as a transitional zone between two distinct zones (Barton \& Hewitt, 1985). A transitional zone can either lead to a positive and desired development or a negative and undesired development. 
In the former case, we need to address the question of whether all the necessary resources are available for growth. In the latter case, we need to ask whether all the resources are available to prevent possible regression.

A classic example of a tension zone is the Zone of Proximal Development first introduced by Vygotsky (1978). The availability of social resources like teachers or peers is considered crucial in this zone (Kuusisaari, 2014). Examples for possible regression can be found in critical life-event research when individuals are threatened to lose balance in their actiotopes.

There are many measurement instruments that can be used to identify tension zones (J. L. Allen, Rapee, \& Sandberg, 2012; Hunt, Rapee, \& Peters, 2012; Lish, Weissman, Adams, Hoven, \& Bird, 1995; Schniering \& Rapee, 2002; Shaffer et al., 1983). However, in our counseling center, we have used clinical interviews thus far (Ziegler, Grassinger, Harder, \& Stöger, 2012).

\section{Basic Educational Principles}

Continuity principle. Gifted education should not be short-sighted, but should try to design what we call learning pathways, that is, planned developmental trajectories, to a desired state. That might be a homeorhetic goal such as eminence (Subotnik et al., 2011) or a homeostatic objective such as self-regulatory competencies (Obergriesser $\&$ Stoeger, 2015). The continuity principle holds that at every point of time on the learning pathway, sufficient exogenous and endogenous learning resources have to be available. Many well-organized educational systems have already realized the continuity principle. For example, when a student completes the fourth grade, there are teachers, a classroom, textbooks, and the like available for fifth grade.

However, gifted education often has to be specifically tailored for a gifted individual, and each actiotope is unique. Therefore, gifted educators have to ensure that gifted individuals have access to the needed learning resources all along their individual learning pathways.

Law of the minimum. The law of the minimum introduced by Ludwig von Liebig in 1840 (see Salisbury, 1992) maintains that growth and development are not controlled by the total amount of available resources, but by the amount of the scarcest resource. Thus, a resource-oriented gifted education perspective must always look for possible limiting factors and should consider possible necessary remediation.

Caution principle: Always expect possible iatrogenic effects. Every action has consequences. In the field of gifted education, hopefully these are the intended consequences. However, actions always have also effects that are unanticipated or unintended (Merton, 1936; Mica, Peisert, \& Winczorek, 2011). Indeed, there is good reason to expect even maladaptation by default; that is, a developmental step might lead to improvements in one respect but might have possible disadvantages in other respects. It is necessary for the educator of gifted students to pay attention to these unintended consequences that are known as iatrogenic effects. 
Iatrogenic effects can be defined as unintentional detrimental effects on resources precipitated, induced, or exacerbated by gifted education. A field that has attracted high attention by researchers is the iatrogenic effect on social capital. For example, being identified as gifted might give an individual access to several gifted education provisions, thus leading to positive consequences. However, researchers (e.g., Freeman, 2006a, 2006b; Heller, 2000, 2004) have pointed out that identification and being labeled as gifted also can lead to negative consequences. For example, peers might retreat, teachers might feel threatened, and this might impede some learning resources and cause various disturbances in the course of personality development (Heller, Reimann, \& Senfter, 2005). Another example is controlling socializations, especially by parents (Garn \& Jolly, 2015; Vialle, 2013). Although parents such as the infamous tiger mothers might be a powerful learning resource, they might also block access to many learning resources necessary for healthy development, such as access to peer friendships.

\section{Learning Resources Management}

Establishing effective control systems: Positive and negative feedback loops. The successful and efficient use of resources has to be regulated in various ways. Thus, in terms of systems theory, control systems have to be established. These are specialized subsystems that decide on, initiate, and monitor the use of resources.

In gifted education research, two forms of control systems have been thoroughly investigated: self-regulation of the gifted learner (Sontag \& Stoeger, 2015; Stoeger, Fleischmann, \& Obergriesser, 2015) and mentoring (Grassinger, Porath, \& Ziegler, 2010). For example, in self-regulated learning, a learner assesses her action repertoire first and then, based on this self-perception, sets a learning goal as the second step. As the third step, she might choose a learning strategy and employ it as the fourth step. The fifth step consists of monitoring her own learning, and as the sixth step, the learner might adapt the learning strategy. Finally, in the seventh step, the learner updates her assessment of her action repertoire before she assesses a new first step in light of the new learning assignment (Stoeger et al., 2015). The execution of such cycles of selfregulated learning provides feedback loops in which not only does learning happen but also the personal learning is improved. Similarly, a mentor can assess the action repertoire of her mentee, set learning goals, and instruct for optimal learning (Grassinger et al., 2010). She monitors the mentee's learning and gives corrective feedback, and then, based on the success of the learning, plans the next learning step.

There are, of course, many more possible control systems. Two simple control systems have been reported regarding former and present chess world champions, Bobby Fischer and Magnus Carlsen. The former replayed the games of chess grandmasters and compared his moves with the moves of his great predecessors. Similarly, Magnus Carlsen played chess games and systematically compared his moves with the moves of chess computers that played at or beyond the level of chess grandmasters. Thus, they both had a constant feedback system that controlled the construction of an effective action repertoire. 
Establishing gifted education support systems. The aforementioned continuity principle and the law of the minimum make clear that there is a constant demand for learning resources in the actiotope. However, it is difficult to guarantee the continuous supply of resources in an actiotope and, in particular, the availability of exactly the resources that are needed for the next learning step. Thus, educators of the gifted should pay considerable attention to the creation of gifted education support systems that function as resource centers. Examples are nongovernmental organizations (NGOs) such as the Texas Association for the Gifted and Talented (TAGT) in the United States or the European Council for High Ability (ECHA) in Europe and gifted counseling centers. However, it is also possible that parents could join together and form a gifted education support system. Another simple example might be when a school establishes a peer mentoring system in which older students help their younger peers.

Externalities management. As previously indicated, every action also has consequences outside the actiotope. We define something as a positive externality if an action ultimately leads to the accumulation of resources in the environment of the actiotope that might potentially flow back as exogenous resources into the actiotope. Similarly, we define something as a negative externality if an action ultimately leads to the buildup of resources in the environment of the actiotope that might potentially prevent the flow of exogenous learning resources into the actiotope.

One way of creating positive externalities and preventing negative externalities is gifted advocacy (Gilman, 2008), that is, all activities that aim to influence decisions favoring gifted education within political, economic, social, and educational systems and institutions. Similarly, Gruber et al. (2008) emphasized the role of "persons in the shadow" who are easily overlooked and may never have direct contact with the individual, but still play an extremely important role. Examples from sports are when team owners and player agents exert an indirect influence on the success of a particular athlete (Hancock, Ste-Mari, \& Schinke, 2010). Similarly, making public the success of a gifted student in nationwide competitions may convince the mayor of a town to improve the conditions for educational programming for that particular student. Thus, the professional regulation of resources should not stop at the boundaries of the actiotope of the gifted individual but must consider the broader context.

\section{Summary and Conclusion}

It is a basic insight that systems must exchange resources to survive (Midgley, 2003; Scott \& Davis, 2007). Based on the Actiotope Model of Giftedness (Ziegler, 2005), we presented a categorization of learning resources. We postulated five exogenous learning resources (educational capital) that gifted individuals need to develop endogenous learning resources (learning capital) and to develop their talents. Such a categorization of resources is useful in itself. It helps to plan and guide gifted education provisions, identify risks as well as strengths for further development, and structure the monitoring of learning progress.

Research has shown that the postulated types of educational capital and learning capital are associated with various desired outcomes such as achievement, professional 
success, self-confidence, and coping with failure (e.g., Vladut et al., 2015; Ziegler et al., 2017). It will be interesting to see how well such a learning-resource-oriented approach will complement traditional gifted education practices.

In this theoretical outline, we linked a learning resource-oriented approach to systems theory (Ziegler, 2005). This was due to the theoretical preferences of the authors; however, this coupling with systems theory is by no means a necessity. A learning resource orientation can probably benefit every gifted educator who aims to offer optimal contexts for gifted development and gifted learning. Nevertheless, the advantage of systems theory is that it already has developed excellent conceptual tools for understanding and analyzing the person-context interaction that simplifies the practical application of a learning resource orientation (Ziegler \& Baker, 2013).

The educational implications that we introduced belonged to four areas. We first argued for a change in the educational orientations of gifted educators. We suggested the adoption of an educational orientation that might be termed positive gifted education. Where gifted educators have focused more on deficits and risk factors (Preckel \& Krampen, 2016), we argued that such a view should be complemented by a resourceoriented perspective that focuses on strength and developmental possibilities. With regard to resource regulation, a positive gifted education orientation can aim for two main goals. One is a homeostatic regulation of the resources, which aims at balance. The other is a homeorhetic regulation of the resources, which aims at growth. Regulation of resources naturally leads to the problems of robustness and resilience. We suggested that these should be one of the central topics of gifted education related to this paradigm.

For gifted identification, two measurement tools for learning resources of the gifted are already available (Harder et al., 2015; Leana-Taşcılar, 2015). They address resources in the environmental component as well as in the individual component of the actiotope. Alternatively, concrete indicators of educational and learning capitals can be assessed (Veas et al., 2017). This might be especially helpful when key resources in a domain need to be addressed. However, it was also suggested that we take a closer look at the synchronization of learning resources and possible tension zones. Whereas synchronization tells the educator of the gifted how many resources are already coordinated with regard to a domain (school learning, chess), the identification of tension zones is important for the regulation of the dynamics of development and learning.

We introduced three representative basic educational principles from a learning resource perspective. The continuity principle reminds the educator of the gifted that resources have been available all along the learning pathway. If the supply is interrupted at any point, a gifted individual might easily give up. The high drop-out rates among the gifted seem to support this occurrence (e.g., Matthews, 2009). The second basic principle introduced was the law of the minimum, which states that growth and development are not controlled by the total amount of available resources, but by the scarcest resource. Thus, a resource orientation also points to where to prioritize. The last basic principle, caution principle, warned us never to forget possible iatrogenic effects of gifted education. A systemic perspective that focuses on interdependencies within the actiotope and also with other systems might be beneficial to identify these. 
The final area of gifted education that was discussed was learning resources management. Again, many things could be said, but we limited ourselves to three suggestions. They referred to the establishment of control systems, gifted support systems, and externalities management. Although sporadic measures have already been taken concerning all the three suggestions, they lack a cohesive and coordinated approach. Now that an exhaustive categorization of learning resources is available, we hope that such an approach based on systems theory can effectively complement traditional gifted education.

\section{Declaration of Conflicting Interests}

The authors declared no potential conflicts of interest with respect to the research, authorship, and/or publication of this article.

\section{Funding}

The authors received no financial support for the research and/or authorship of this article.

\section{References}

Aberg, M. A. I., Pedersen, N. L., Torén, K., Svartengren, M., Bäckstrand, B., Johnsson, T., \& Kuhn, H. G. (2009). Cardiovascular fitness is associated with cognition in young adulthood. Proceedings of the National Academy of Sciences of the United States of America, 106, 20906-20911. doi:10.1073/pnas.0905307106

Allen, C. R., \& Holling, C. S. (2008). Cross-scale structure and the generation of innovation and novelty in discontinuous complex systems. In C. R. Allen \& C. S. Holling (Eds.), Discontinuities in ecosystems and other complex systems (pp. 219-233). New York, NY: Columbia University Press.

Allen, J. L., Rapee, R. M., \& Sandberg, S. (2012). Assessment of maternally reported life events in children and adolescents: A comparison of interview and checklist methods. Journal of Psychopathology and Behavioral Assessment, 34, 204-215. doi:10.1007/s10862-011-9270-5

Ammermüller, A., \& Lauer, C. (2007). Bildung und nationale Prosperität [Education and national prosperity]. In K. A. Heller \& A. Ziegler (Eds.), Begabt sein in Deutschland (pp. 31-48). Münster, Germany: LIT Verlag.

Anger, C., Plünnecke, A., \& Tröger, M. (2007). Renditen der Bildung-Investitionen in den frühkindlichen Bereich [Yields of education-Investing in early childhood]. Retrieved from http://www.iwkoeln.de/_storage/asset/63785/storage/master/file/355768/download/ dokumente_0207_studie-9.pdf

Bandura, A., Barbaranelli, C., Caprara, G. V., \& Pastorelli, C. (2001). Self-efficacy beliefs as shapers of children's aspirations and career trajectories. Child Development, 72, 187-206. doi:10.1111/1467-8624.00273

Barab, S. A., \& Plucker, J. A. (2002). Smart people or smart contexts? Cognition, ability, and talent development in an age of situated approaches to knowing and learning. Educational Psychologist, 37, 165-182. doi:10.1207/S15326985EP3703_3

Barton, N. H., \& Hewitt, G. M. (1985). Analysis of hybrid zones. Annual Review of Ecology and Systematics, 16, 113-148. doi:10.1146/annurev.es.16.110185.000553

Baumert, J., Stanat, R., \& Watermann, R. (Eds.). (2006). Disparitäten im Bildungswesen: Differenzielle Bildungsprozesse und Probleme der Verteilungsgerechtigkeit [Disparities in education: Differential educational processes and problems of distributive justice]. Wiesbaden, Germany: VS Verlag für Sozialwissenschaften. 
Beamish, R. (1990). The persistence of inequality: An analysis of participation patterns among Canada's high performance athletes. International Review for the Sociology of Sport, 25, $143-155$.

Bloom, B. S. (1984). The 2 sigma problem: The search for methods of group instruction as effective as one-to-one tutoring. Educational Researcher, 13(6), 4-16.

Chaddock, L., Hillman, C. H., Buck, S. M., \& Cohen, N. J. (2011). Aerobic fitness and executive control of relational memory in preadolescent children. Medicine \& Science in Sports \& Exercise, 43, 344-349. doi:10.1249/MSS.0b013e3181e9af48

Chi, M. T. H., Glaser, R., \& Farr, M. J. (1988). The nature of expertise. Hillsdale, NJ: Lawrence Erlbaum.

Coyle, D. (2009). The talent code: Greatness isn't born. It's grown. Here's how. New York, NY: Bantam.

Cunha, F., \& Heckman, J. (2007). The technology of skill formation. American Economic Review, 97, 31-47. doi:10.1257/aer.97.2.31

Curcio, G., Ferrara, M., \& De Gennaro, L. (2006). Sleep loss, learning capacity and academic performance. Sleep Medicine Reviews, 10, 323-337. doi:10.1016/j.smrv.2005.11.001

Dai, D. Y., \& Chen, F. (2013). Three paradigms of gifted education: In search of conceptual clarity in research and practice. Gifted Child Quarterly, 57, 151-168. doi: $10.1177 / 0016986213490020$

Darling-Hammond, L. (2000). Teacher quality and student achievement: A review of state policy evidence. Education Policy Analysis Archives, 8, 1-44. doi:10.14507/epaa.v8n1.2000

Davidson, J. W., Howe, M. J., Moore, D. G., \& Sloboda, J. A. (1996). The role of parental influences in the development of musical performance. British Journal of Developmental Psychology, 14, 399-412. doi:10.1111/j.2044-835X.1996.tb00714.x

Debatin, T., Hopp, M., Vialle, W., \& Ziegler, A. (2015). Why experts can do what they do: The effects of exogenous resources on the Domain Impact Level on Activities (DILA). Psychological Testing and Assessment Modeling, 57, 94-110.

Dettmers, S., Trautwein, U., Lüdtke, O., Kunter, M., \& Baumert, J. (2010). Homework works if homework quality is high: Using multilevel modeling to predict the development of achievement in mathematics. Journal of Educational Psychology, 102, 467-482. doi: $10.1037 / \mathrm{a} 0018453$

Ditton, H., \& Krüsken, J. (2009). Bildungslaufbahnen im differenzierten Schulsystem. Entwicklungsverläufe von Bildungsaspirationen und Laufbahnempfehlungen in der Grundschulzeit [Educational careers in the differentiated school system. Courses of development of educational aspirations and career recommendations in elementary school]. Zeitschrift für Erziehungswissenschaft, 12, 74-102. doi:10.1007/ 978-3-531-92216-4_4

Downey, D. B., \& Vogt Yuan, A. S. (2005). Sex differences in school performance during high school: Puzzling patterns and possible explanations. The Sociological Quarterly, 46, 299-321. doi:10.1111/j.1533-8525.2005.00014.x

Dweck, C. S. (1999). Self-theories: Their role in motivation, personality, and development. Philadelphia, PA: Psychology Press.

Ehmke, T., \& Jude, N. (2010). Soziale Herkunft und Kompetenzerwerb [Social background and competence acquisition]. In E. Klieme et al. (Eds.), PISA 2009: Bilanz nach einem Jahrzehnt (pp. 231-254). Münster, Germany: Waxmann.

Ekelund, U., Luan, J., Sherar, L. B., Esliger, D. W., Griew, P., Cooper, A., \& International Children's Accelerometry Database Collaborators. (2012). Moderate to vigorous physical activity and sedentary time and cardiometabolic risk factors in children and adolescents. Journal of the American Medical Association, 307, 704-712. doi:10.1001/jama.2012.156 
Ericsson, K. A. (1996). The acquisition of expert performance: An introduction to some of the issues. In K. A. Ericsson (Ed.), The road to excellence: The acquisition of expert performance in the arts and sciences, sports, and games (pp. 1-50). Mahwah, NJ: Lawrence Erlbaum.

Ericsson, K. A. (2001). The path to expert performance: Insights from the masters on how to improve performance by deliberate practice. In P. Thomas (Ed.), Optimizing performance in golf (pp. 1-57). Brisbane, Australia: Australian Academic Press.

Ericsson, K. A. (2003). The development of elite performance and deliberate practice: An update from the perspective of the expert-performance approach. In J. Starkes \& K. A. Ericsson (Eds.), Expert performance in sports: Advances in research on sport expertise (pp. 49-81). Champaign, IL: Human Kinetics.

Ericsson, K. A. (2006). The influence of experience and deliberate practice on the development of superior expert performance. In K. A. Ericsson, N. Charness, P. Feltovich, \& R. R. Hoffman (Eds.), Cambridge handbook of expertise and expert performance (pp. 685-706). Cambridge, MA: Cambridge University Press.

Ericsson, K. A., Charness, N., Feltovich, P. J., \& Hoffman, R. R. (Eds.). (2006). The Cambridge handbook of expertise and expert performance. New York, NY: Cambridge University Press.

Ericsson, K. A., Krampe, R. T., \& Tesch-Romer, C. (1993). The role of deliberate practice in the acquisition of expert performance. Psychological Review, 100, 363-406. doi:10.1037/0033295X.100.3.363

Feldhusen, J. (1982). Myth: Gifted education means having a program! Meeting the needs of gifted students through differentiated programming. Gifted Child Quarterly, 26, 37-41.

Fletcher, I. M., \& Jones, B. (2004). The effect of different warm-up stretch protocols on 20 meter sprint performance in trained rugby union players. Journal of Strength and Conditioning Research, 18, 885-888.

Freeman, J. (2006a). Emotional problems of the gifted child. Journal of Child Psychology and Psychiatry, 24, 481-485. doi:10.1111/j.1469-7610.1983.tb00123.x

Freeman, J. (2006b). Giftedness in the long term. Journal for the Education of the Gifted, 29, 384-403. doi:10.4219/jeg-2006-246

Fuligni, A. J. (1997). The academic achievement of adolescents from immigrant families: The role of family background, attitudes, and behavior. Child Development, 68, 351-363. doi:10.1111/j.1467-8624.1997.tb01944.x

Garn, A. C., \& Jolly, J. L. (2015). A model of parental achievement-oriented psychological control in academically gifted students. High Ability Studies, 26, 105-116. doi:10.1080/13 598139.2015.1028614

Gilman, B. J. (2008). Academic advocacy for gifted children: A parent's complete guide. Scottsdale, AZ: Great Potential Press.

Grassinger, R., Porath, M., \& Ziegler, A. (2010). Mentoring: Conceptual foundations and effectivity analysis. High Ability Studies, 21, 27-46. doi:10.1080/13598139.2010.488087

Gruber, H., Lehtinen, E., Palonen, T., \& Degner, S. (2008). Persons in the shadow: Assessing the social context of high abilities. Psychology Science Quarterly, 50, 237-258.

Gunderson, L. H., Folke, C., \& Janssen, M. (2006). Generating and fostering novelty. Ecology and Society, 11(1), Article 50.

Hancock, D. J., Ste-Mari, D. M., \& Schinke, R. J. (2010). The development and skills of expert major junior hockey player agents. Talent Development \& Excellence, 2, 51-62.

Hanushek, E. A., \& Kimko, D. D. (2000). Schooling, labor force quality, and the growth of nations. American Economic Review, 90, 1184-1208. doi:10.1257/aer.90.5.1184 
Harackiewicz, J. M., Barron, K. E., Tauer, J. M., \& Elliot, A. J. (2002). Predicting success in college: A longitudinal study of achievement goals and ability measures as predictors of interest and performance from freshman year through graduation. Journal of Educational Psychology, 94, 562-575. doi:10.1037/0022-0663.94.3.562

Harder, B., Trottler, S., Vialle, W., \& Ziegler, A. (2015). Diagnosing resources for effective learning via teacher and parent checklists. Psychological Test and Assessment Modeling, 57, 201-221.

Harder, B., Trottler, S., \& Ziegler, A. (2013). Die Entwicklung der Nürnberger Bildungs- und Lernkapital Checkliste [Development of the Nuremberg Educational and Learning Capital Checklist]. Journal für Begabtenförderung, 13(2), 37-47.

Hattie, J. (2008). Visible learning: A synthesis of over 800 meta-analyses relating to achievement. London, England: Routledge.

Hattie, J., Biggs, J., \& Purdie, N. (1996). Effects of learning skills interventions on student learning: A meta-analysis. Review of Educational Research, 66, 99-136. doi:10.3102/00346543066002099

Heller, K. A. (2000). Hochbegabung im Kindes- und Jugendalter [Giftedness in childhood and adolescence]. Göttingen, Germany: Hogrefe Verlag.

Heller, K. A. (2004). Identification of gifted and talented students. Psychology Science, 46, 302-323.

Heller, K. A., Reimann, R., \& Senfter, A. (2005). Hochbegabung im Grundschulalter: Erkennen und Foerdern [Identification of the gifted in preschool and elementary school]. Münster, Germany: LIT.

Hong, S., \& Ho, H.-Z. (2005). Direct and indirect longitudinal effects of parental involvement on student achievement: Second-order latent growth modeling across ethnic groups. Journal of Educational Psychology, 97, 132-142. doi:10.1037/00220663.97.1.32

Hunt, C., Rapee, R. M., \& Peters, L. (2012). Development of a measure of the experience of being bullied in youth. Psychological Assessment, 24, 156-165. doi:10.1037/a0025178

Institut der deutschen Wirtschaft Köln. (2015). Bildungsmonitor 2015. Ein Blick auf Bachelor und Master [Educational Monitor 2015. A look at Bachelor and Master]. Retrieved from http://www.insm-bildungsmonitor.de/pdf/Forschungsbericht_BM_Langfassung.pdf

Jablonka, E., \& Lamb, M. J. (2005). Evolution in four dimensions: Genetic, epigenetic, behavioral, and symbolic variation in the history of life. Cambridge, MA: MIT Press.

Jeltova, I., \& Grigorenko, E. L. (2005). Systemic approaches to giftedness: Contributions of Russian psychology. In R. J. Sternberg \& J. E. Davidson (Eds.), Conceptions of giftedness (pp. 171-186). Cambridge, MA: Cambridge University Press.

Kelso, J. A. S. (2003). Cognitive coordination dynamics. In W. Tschacher \& J.-P. Dauwalder (Eds.), The dynamical systems approach to cognition: Concepts and empirical paradigms based on self-organization, embodiment and coordination dynamics (pp. 45-71). Singapore: World Scientific.

Kitano, H. (2004). Biological robustness. Nature Review Genetics, 5, 826-837. doi:10.1038/ $\operatorname{nrg} 1471$

Klein, J. (2001). Attention, scholastic achievement and timing of lessons. Scandinavian Journal of Educational Research, 45, 301-309. doi:10.1080/00313830120074224

Klieme, E. (2004). Begründung, Implementation und Wirkung von Bildungsstandards: Aktuelle Diskussionslinien und empirische Befunde [Justification, implementation and impact of educational standards: Current lines of discussion and empirical findings]. Zeitschrift für Pädagogik, 50, 625-634. 
Kuusisaari, H. (2014). Teachers at the Zone of Proximal Development: Collaboration promoting or hindering the development process. Teaching and Teacher Education, 43, 46-57. doi:10.1016/j.tate.2014.06.001

Leana-Taşc1lar, M. Z. (2015). The Actiotope Model of Giftedness: Its relationship with motivation, and the prediction of academic achievement among Turkish students. The Australian Educational and Developmental Psychologist, 32, 41-55. doi:10.1017/edp.2015.6

Lee, V. E., \& Bryk, A. S. (1989). A multilevel model of the social distribution of high school achievement. Sociology of Education, 62, 172-192. doi:10.2307/2112866

Lehmann, M., Gastmann, U., Petersen, K. G., Bachl, N., Seidel, A., Khalaf, A. N., \& Keul, J. (1992). Training-overtraining: Performance, and hormone levels, after a defined increase in training volume versus intensity in experienced middle- and long-distance runners. British Journal Sports Medicine, 26, 233-242. doi:10.1136/bjsm.26.4.233

Lerner, R., \& Overton, W. F. (2008). Exemplifying the integrations of the relational developmental system: Synthesizing theory, research, and application to promote positive development and social justice. Journal of Adolescence Research, 23, 245-255. doi: $10.1177 / 0743558408314385$

Li, J. (2004). A Chinese cultural model of learning. In L. Fan, N.-Y. Wong, J. Cai, \& S. Li (Eds.), How Chinese learn mathematics: Perspectives form insiders (pp. 124-156). Singapore: World Scientific.

Lish, J. D., Weissman, M. M., Adams, P. B., Hoven, C. W., \& Bird, H. (1995). Family psychiatric screening instrument for epidemiologic studies: Pilot testing and validation. Psychiatry Research, 57, 169-180. doi:10.1016/0165-1781(95)02632-7

Lupatsch, J., \& Hadjar, A. (2011). Determinanten des Geschlechterunterschieds im Schulerfolg: Ergebnisse einer quantitativen Studie aus Bern [Determinants of gender differences in educational attainment: Results of a quantitative study from Bern]. In A. Hadja (Ed.), Geschlechtsspezifische Bildungsungleichheiten (pp. 177-202). Wiesbaden, Germany: VS Verlag für Sozialwissenschaften.

Lynn, R., \& Vanhanen, T. (2002). IQ and the wealth of nations. Westport, CT: Praeger.

MacLeod, J. (1987). Ain't no makin' it: Leveled aspiration in low-income neighborhood. Boulder, CO: Westview Press.

Mandl, H., \& Friedrich, H. F. (2006). Handbuch Lernstrategien [Handbook of learning strategies]. Göttingen, Germany: Hogrefe.

Manturzewska, M. (1990). A biographical study of the life-span development of professional musicians. Psychology of Music, 18, 112-139. doi:10.1177/0305735690182002

Maslow, A. H. (1987). Motivation and personality (3rd ed.). New York, NY: Harper \& Row.

Matthews, M. S. (2009). Gifted learners who drop out: Prevalence and prevention. In L. V. Shavinina (Ed.), International handbook on giftedness (pp. 527-536). New York, NY: Springer.

McElvany, N., Becker, M., \& Lüdtke, L. (2009). Die Bedeutung familiärer Merkmale für Lesekompetenz, Wortschatz, Lesemotivation und Leseverhalten [The importance of family characteristics on reading skills, vocabulary, reading motivation and behavior]. Entwicklungspsychologie und Pädagogische Psychologie, 41, 121-131. doi:10.1026/00498637.41.3.121

McInerney, D. M. (2008). Personal investment, culture and learning: Insights into school achievement across Anglo, Aboriginal, Asian and Lebanese students in Australia. International Journal of Psychology, 43, 870-879. doi:10.1080/00207590701836364

Merton, R. K. (1936). The unanticipated consequences of purposive social action. American Sociological Review, 1, 894-904. 
Mica, A., Peisert, A., \& Winczorek, J. (Eds.). (2011). Sociology and the unintended: Robert Merton revisited. Frankfurt am Main, Germany: Peter Lang.

Midgley, G. (Ed.). (2003). Systems thinking. London, England: Sage.

Mirman, N. J. (2003). Identifying and selecting teachers. In J. F. Smutny (Ed.), Designing and developing programs for gifted students (pp. 39-47). Thousand Oaks, CA: Corwin Press.

Mößle, T., Kleimann, M., Rehbein, F., \& Pfeiffer, C. (2006). Mediennutzung, Schulerfolg, Jugendgewalt und die Krise der Jungen [Media usage, school success, youth violence and the crisis of boys]. Zeitschrift für Jugendkriminalrecht und Jugendhilfe, 3, 295-309.

Obergriesser, S., \& Stoeger, H. (2015). The role of emotions, motivation, and learning behavior for underachievement and results of an intervention. High Ability Studies, 26, 167-190. doi:10.1080/13598139.2015.1043003

Oh, H., Sutherland, M., Stack, N., del Mar Badia Martín, M., Blumen, S., Nguyen, A.-T., . . . Ziegler, A. (2015). A cross-cultural study of possible iatrogenic effects of gifted education programs: Tenth graders' perceptions of academically high performing classmates. High Ability Studies, 26, 152-166. doi:10.1080/13598139.2015.1044080

Organisation for Economic Co-Operation and Development. (2001). Knowledge and skills for life: First results from PISA 2000. Retrieved from https://www.oecd.org/edu/school/programmeforinternationalstudentassessmentpisa/33691620.pdf

Paschal, R. A., Weinstein, T., \& Walberg, H. J. (1984). The effects of homework on learning: A quantitative synthesis. The Journal of Educational Research, 78, 97-104. doi:10.1080/0 0220671.1984.10885581

Phillipson, S. N., Stoeger, H., \& Ziegler, A. (Eds.). (2013). Exceptionality in East-Asia: Explorations in the Actiotope Model of Giftedness. London, England: Routledge.

Plucker, J. A., \& Barab, S. A. (2005). The importance of contexts in theories of giftedness: Learning to embrace the messy joys of subjectivity. In R. J. Sternberg \& J. E. Davidson (Eds.), Conceptions of giftedness (pp. 201-216). Cambridge, MA: Cambridge University Press.

Preckel, F., \& Krampen, G. (2016). Entwicklung und Schwerpunkte in der psychologischen Hochbegabungsforschung [Development and focal points in the psychological giftedness research]. Psychologische Rundschau, 67, 1-14. doi:10.1026/0033-3042/a000289

Reis, S. M. (2005). Feminist perspectives on talent and development: A research-based conception of giftedness in women. In R. J. Sternberg \& J. E. Davidson (Eds.), Conceptions of giftedness (pp. 201-216). Cambridge, MA: Cambridge University Press.

Rindermann, H., Sailer, M., \& Thompson, J. (2009). The impact of smart fractions, cognitive ability of politicians and average competence of peoples on social development. Talent Development \& Excellence, 1, 3-25.

Roring, R. W. (2008). Reviewing expert chess performance: A production-based theory of chess skill (Doctoral dissertation, Florida State University). Retrieved from http://diginole.lib.fsu. edu/islandora/object/fsu:176256/datastream/PDF/view

Ryan, A. M. (2000). Peer groups as a context for the socialization of adolescents' motivation, engagement, and achievement in school. Educational Psychologist, 35, 101-111. doi:10.1207/S15326985EP3502_4

Salisbury, F. (1992). Plant physiology (4th ed.). Belmont, CA: Wadsworth.

Schneider, B., \& Lee, Y. (1990). A model for academic success: The school and home environment of East Asian students. Anthropology \& Education Quarterly, 21, 358-377. doi:10.1525/aeq.1990.21.4.04x0596x

Schniering, C. A., \& Rapee, R. M. (2002). Development and validation of a measure of children's automatic thoughts: The Children's Automatic Thoughts Scale. Behavior Research and Therapy, 40, 1091-1109. doi:10.1016/S0005-7967(02)00022-0 
Scott, W. R., \& Davis, G. F. (2007). Organizations and organizing: Rational, natural, and open system perspectives. London, England: Routledge.

Seidel, T., \& Shavelson, R. J. (2007). Teaching effectiveness research in the past decade: The role of theory and research design in disentangling meta-analysis results. Review of Educational Research, 77, 454-499. doi:10.3102/0034654307310317

Seligman, E. P., \& Csikszentmihalyi, M. (2000). Positive psychology: An introduction. American Psychologist, 55, 5-14. doi:10.1037//0003-066X.55.1.5

Shaffer, D., Gould, M. S., Brasic, J., Ambrosini, P., Fisher, P., Bird, H., \& Aluwahlia, S. (1983). A Children's Global Assessment Scale (CGAS). Archives of General Psychiatry, 40, 1228 1231. doi:10.1001/archpsyc.1983.01790100074010

Shavinina, L. V. (Ed.). (2009). International handbook on giftedness. New York, NY: Springer.

Shek, D. T. L., \& Chan, L. K. (1999). Hong Kong Chinese parents' perceptions of the ideal child. Journal of Psychology: Interdisciplinary and Applied, 133, 291-302. doi:10.1080/00223989909599742

Shih, M., Pittinsky, T. L., \& Ambady, N. (1999). Stereotype susceptibility: Identity, salience and shifts in quantitative performance. Psychological Science, 10, 80-83. doi:10.1111/14679280.00111

Shore, S. M., Sachs, M. L., Lidicker, J. R., Brett, S. N., Wright, A. R., \& Libonati, J. R. (2008). Decreased scholastic achievement in overweight middle school students. Obesity, 16, 1535-1538. doi:10.1038/oby.2008.254 2008

Simonton, D. K. (2005). Genetics of giftedness: The implications of an emergenic-epigenetic model. In R. J. Sternberg \& J. E. Davidson (Eds.), Conceptions of giftedness (pp. 312-326). Cambridge, MA: Cambridge University Press.

Smith, C. (2001). Sleep states and memory processes in humans: Procedural versus declarative memory systems. Sleep Medicine Reviews, 5, 491-506. doi:10.1053/smrv.2001.0164

Sontag, C., \& Stoeger, H. (2015). Can highly intelligent and high-achieving students benefit from a training of self-regulated learning in a regular classroom context? Learning and Individual Differences, 41, 43-53. doi:10.1016/j.lindif.2015.07.008

Sotelo-Dynega, M., Ortiz, S. O., Flanagan, D. P., \& Chaplin, W. (2013). English language proficiency and test performance: An evaluation of bilinguals with the Woodcock-Johnson III Tests of Cognitive Abilities. Psychology in the Schools, 50, 791-797. doi:10.1002/pits.21706

Starkes, J., \& Ericsson, K. A. (Eds.). (2003). Expert performance in sports: Advances in research on sport expertise. Champaign, IL: Human Kinetics.

Starr, W. (1976). The Suzuki violinist: A guide for teachers and parents. Secaucus, NY: Warner.

Statista. (2016). Number of Nobel Prize Laureates in physics from 1901 to 2016, by nationality. Retrieved from https://www.statista.com/statistics/262900/nobel-prize-laureates-inphysics-by-nationality/

Steele, C. M. (1997). A threat in the air: How stereotypes shape intellectual identity and performance. American Psychologist, 52, 613-629. doi:10.1037/0003-066X.52.6.613

Sternberg, R. J., \& Davidson, J. E. (Eds.). (2005). Conceptions of giftedness (2nd ed.). New York, NY: Cambridge University Press.

Stevenson, H. W., Lee, S. Y., \& Stigler, J. W. (1986). Mathematics achievement of Chinese, Japanese, and American children. Science, 231, 693-699.

Stoeger, H. (2007). Berufskarrieren begabter Frauen [Careers of gifted women]. In K. A. Heller \& A. Ziegler (Eds.), Begabt sein in Deutschland (pp. 266-290). Berlin, Germany: LIT.

Stoeger, H., Fleischmann, S., \& Obergriesser, S. (2015). Self-regulated learning (SRL) and the gifted learner in primary school: The theoretical basis of and empirical findings on a research program dedicated to ensuring that all students learn to regulate their own learning. Asia Pacific Education Review, 16, 257-267. doi:10.1007/s12564-015-9376-7 
Stoeger, H., Ziegler, A., \& Schimke, D. (2009). Mentoring: Theoretische Hintergründe, empirische Befunde und praktische Anwendungen [Mentoring: Theoretical background, empirical results, and practical implementation]. Lengerich, Germany: Pabst.

Subotnik, R. F., Olszewski-Kubilius, P., \& Worrell, F. C. (2011). Rethinking giftedness and gifted education: A proposed direction forward based on psychological science. Psychological Science in the Public Interest, 12, 3-54. doi:10.1177/1529100611418056

Suchań, B., \& Bergmüller, S. (2010). Leistungsunterschiede zwischen Schulen [Performance differences between schools]. In B. Suchań, C. Wallner-Paschon, \& C. Schreiner (Eds.), TIMSS 2007. Mathematik und Naturwissenschaft in der Grundschule (pp. 214-231). Graz, Austria: Leykam.

Valsiner, J., \& Rosa, A. (Eds.). (2007). Cambridge handbook of sociocultural psychology. New York, NY: Cambridge University Press.

Veas, A., Castejón, J.-L., O'Reilly, C., \& Ziegler, A. (2017). Mediation analysis of the relationship between educational capital, learning capital and underachievement among gifted secondary school students. Manuscript submitted for publication.

Vialle, W. (2013). The "tiger mother" factor: Curriculum, schooling and mentoring of Asian students in an Australian context. In S. N. Phillipson, H. Stoeger, \& A. Ziegler (Eds.), Exceptionality in East-Asia: Explorations in the Actiotope Model of Giftedness (pp. 147166). London, England: Routledge.

Vladut, A., Liu, Q., Leana-Taşcilar, M., Vialle, W., \& Ziegler, A. (2013). A cross-cultural validation study of the Questionnaire of Educational and Learning Capital (QELC) in China, Germany and Turkey. Psychological Test and Assessment Modeling, 55, 462-478.

Vladut, A., Vialle, W., \& Ziegler, A. (2015). Learning resources within the actiotope: A validation study of the QELC (Questionnaire of Educational and Learning Capital). Psychological Testing and Assessment Modeling, 57, 40-56.

Vygotsky, L. S. (1978). Mind in society: The development of higher psychological processes. Cambridge, MA: Harvard University Press.

Ziegler, A. (2005). The Actiotope Model of Giftedness. In R. Sternberg \& J. E. Davidson (Eds.), Conceptions of giftedness (pp. 411-434). Cambridge, UK: Cambridge University Press.

Ziegler, A., \& Baker, J. (2013). Talent development as adaption: The role of educational and learning capital. In S. Phillipson, H. Stoeger, \& A. Ziegler (Eds.), Exceptionality in EastAsia: Explorations in the Actiotope Model of Giftedness (pp. 18-39). London, England: Routledge.

Ziegler, A., Debatin, T., \& Stoeger, H. (2017). Learning resources and talent development from a systemic point of view. Manuscript submitted for publication.

Ziegler, A., Grassinger, R., Harder, B., \& Stöger, H. (2012). Das Beratungskonzept der Landesweiten Beratungs- und Forschungsstelle für Hochbegabung (LBFH) [The counseling concept of the state-wide office for giftedness counseling and research (LBFH)]. In A. Ziegler, R. Grassinger, \& B. Harder (Eds.), Konzepte der Hochbegabtenberatung in der Praxis (pp. 96-128). Münster, Germany: LIT.

Ziegler, A., \& Phillipson, S. (2012). Towards a systemic theory of gifted education. High Ability Studies, 23, 3-30. doi:10.1080/13598139.2012.679085

Ziegler, A., \& Stoeger, H. (2016). Gifted identification kit 4-6 for the United Arab Emirates. Dubai, United Arab Emirates: Hamdan Award for Distinguished Academic Performance.

Ziegler, A., Stoeger, H., \& Balestrini, D. (2017). Systemic gifted education. In J. R Cross, C. O'Reilly, \& T. L. Cross (Eds.), Providing for the special needs of students with gifts and talents (pp. 15-55). Dublin, Ireland: CTYI Press.

Ziegler, A., Stoeger, H., \& Vialle, W. (2012). Giftedness and gifted education: The need for a paradigm change. Gifted Child Quarterly, 46, 194-197. doi:10.1177/0016986212456070 
Ziegler, A., Vialle, W., \& Wimmer, B. (2013). The Actiotope Model of Giftedness: A short introduction to some central theoretical assumptions. In S. Phillipson, H. Stoeger, \& A. Ziegler (Eds.), Exceptionality in East-Asia: Explorations in the Actiotope Model of Giftedness (pp. 1-17). London, England: Routledge.

\section{Author Biographies}

Albert Ziegler, $\mathrm{PhD}$, is chair professor of Educational Psychology and Research on Excellence at the University of Erlangen-Nuremberg, Germany. He is the founding director of the StateWide Counseling and Research Centre for the Gifted. He has published approximately 300 books, chapters, and articles in the fields of talent development, excellence, educational psychology, and cognitive psychology. Presently, he serves as the secretary-general of the International Research Association for Talent Development and Excellence (IRATDE). He is also the vice-president of the European Council for High Ability (ECHA) and the Chairman of the European Talent Support Network (ETSN). His main interests in the field of talent development and excellence are the development of exceptional performance, the Actiotope Model of Giftedness, educational and learning capital, sociotopes, and motivational training programs.

Kimberley L. Chandler, $\mathrm{PhD}$, is the curriculum director at the Center for Gifted Education at William \& Mary and a clinical assistant professor. Her professional background includes teaching gifted students in a variety of settings, serving as an administrator of a school district gifted program, and providing professional development for teachers and administrators nationally and internationally. She coauthored the book Effective Curriculum for Underserved Gifted Students and is the coeditor of Effective Program Models for Gifted Students From Underserved Populations. She is the guest editor of a special issue of Journal for the Education of the Gifted $(J E G)$, one of two issues in the volume focusing on international practices in gifted education. Currently, she is coauthor of "The Primary Place" column in Teaching for High Potential and the editor of the Council for Exceptional Children-The Association for the Gifted (CEC-TAG) newsletter "The Update." Her research interests include curriculum policy and implementation issues in gifted programs, the design and evaluation of professional development programs for teachers of the gifted, and the role of principals in gifted education.

Wilma Vialle, $\mathrm{PhD}$, is a full professor in educational psychology and associate dean of the Faculty of Education, University of Wollongong. She teaches child development and psychological foundations of education and gifted education, and supervises a number of postgraduate research students in related fields. Her interests are predominantly in the nature of intelligence and creativity, with a particular focus on giftedness. She has published extensively on topics related to giftedness and children's learning. She is the chief editor of the Australasian Journal of Gifted Education and is on the editorial board of several international journals. In 2006, she was awarded the Eminent Australian for her contributions to gifted education.

Heidrun Stoeger, PhD, is a full professor of education at University of Regensburg, Germany. She holds the chair for School Research, School Development, and Evaluation. She has published books, chapters, and articles in the fields of talent development, educational psychology, and education. She is also editor-in-chief of the journal High Ability Studies and member of the editorial board of the German Journal of Talent Development. Her main interests in the field of talent development and excellence are underachievement, teacher training, the Actiotope Model of Giftedness, and learning and motivational training programs. 